\title{
Mariusz PIESTRAK
}

Karolina KICHEWKO

Wrocław

\section{Rola lobbingu w polskich stosunkach przemysłowych}

\section{Słowo wstępne}

0 grupach interesu napisano już wiele. Były one przedmiotem analiz o różnorakim podłożu, jedne snute były na gruncie historycznym, inne ekonomicznym, a jeszcze inne traktowały interesujące nas organizacje w kontekście stricte politologicznym. Autorów niniejszego tekstu zajmować będzie właśnie ten ostatni kontekst, który „każe” nam traktować grupy interesu jako funkcjonalną część systemu politycznego, jako podmioty zainteresowane wpływem na polityczny proces decyzyjny.

Kontekst ten będzie jednak nieco zmodyfikowany w dalszej części rozważań, albowiem to nie grupom interesu będziemy się szczegółowo przyglądać, ale ich strategii, określanej terminem dobrze (na pozór) znanym - lobbing. Idąc nieco dalej (uszczegółowiając) powiemy, że piszący te słowa wyznaczyli sobie jako cel artykułu nie tyle samo zaprezentowanie problematyki lobbingu, ale prezentację argumentów przemawiających za traktowaniem lobbingu jako części składowej stosunków przemysłowych. Wyznacza to nam konkretny kierunek analityczny, a mianowicie orientację na relacje przebiegające pomiędzy wielkimi ekonomicznymi grupami interesu a państwem, z opcjonalną możliwością uwzględnienia roli grup interesu o mniejszej sile.

\section{Zagadnienia wstępne}

Zastanawiając się nad istotą i znaczeniem strategii stosowanych przez organizacje grup interesu w obrębie stosunków przemysłowych, autorzy niniejszego tekstu zwrócili uwagę na dwa zagadnienia. Co prawda były one już podejmowane w literaturze wcześniej ${ }^{1}$, ale $\mathrm{z}$ racji ich ważkości, piszący te słowa, postanowili je ponownie, acz szczegółowo, przeanalizować, wykorzystując w tym celu najnowsze doświadczenia rodzimej sceny przemysłowej. Pierwsza newralgiczna kwestia mówi o tym, iż z racji tego, że akcja kolektywna jest „motorem” napędowym działań przebiegających na arenie stosunków przemysłowych to i lobbing, będący w gruncie rzeczy ,jakimś” obliczem tejże akcji kolektywnej, jest ,popularnym” składnikiem stosunków przemysłowych. Drugie zagadnienie traktuje o dyferencji w natężeniu stosowania lobbingu wynikającej z panującego w danym kraju modelu stosunków przemysłowych.

Zagadnienia te zostaną rozwinięte $\mathrm{w}$ dalszej części tekstu. By stało się to możliwe postanowiliśmy w pierwszej kolejności poświęcić się rozważaniom teoretycznym, w ramach których wskażemy na tak istotne zagadnienia, jak interes polityczny, grupy interesu oraz (przede

\footnotetext{
${ }^{1}$ Np. J. Sroka, Polityka organizacji pracodawców i przedsiębiorców, Wydawnictwo Uniwersytetu Wrocławskiego, Wrocław 2004.
} 
wszystkim) pochylimy się nad kategorią lobbingu. Pozwoli to nam w dalszej kolejności przejść do części drugiej tekstu, zgłębiającej praktyki polskiego lobbingu.

\section{Uporządkowany chaos terminologiczny}

Z pozoru wydawać by się mogło, że każda z interesujących nas kategorii jest trudno definiowalnym zjawiskiem. Wniosek taki wysnuć możemy choćby z uwagi na bogactwo i różnorodność propozycji definicyjnych. Niemniej jednak wielość definicji czy też wielość ujęć, przez które patrzy się na owe kategorie, jest zjawiskiem wywołującym jedynie złudny chaos teoretyczny. Stąd też w celu utrzymania przejrzystości wywodu najpierw wyjaśnimy podstawowe kategorie analityczne w tej materii, dopiero w dalszej części przechodząc do empirii.

Gdybyśmy mieli podać definicję stosunków przemysłowych, to moglibyśmy po prostu powiedzieć, że ich istota sprowadza się do szeroko rozumianych stosunków pracy. I w zasadzie nie byłby to błąd definicyjny, ale też nie byłaby to szeroka i wyczerpująca formuła definicyjna, zwłaszcza gdy rozpatrujemy stosunki przemysłowe w ujęciu politologicznym. Chodzi tu bowiem o to, że wyjaśnienie ich poprzez relacje społeczne ujawniające się w procesie pracy jest politologicznie daleko niewystarczające. Rzecz w tym, że ujawniają się tu pewne polityczne konotacje, które widoczne są w politycznym uwikłaniu aktorów stosunków pracy.

Najbardziej adekwatna w tym względzie wydaje się być definicja J. Sroki, który uznaje je (stosunki przemysłowe) za podsystem systemu politycznego, w obrębie którego podmioty reprezentujace pracodawców i pracowników [czy też szerzej grupy interesu - przyp. aut.] staraja się wywierać wplyw na parametry ,, ustroju” pracy, a także ksztaltować kurs gospodarczych, socjalnych oraz fiskalnych programów administracyjnych ${ }^{2}$. Grupy te zorientowane są na swój interes, co rozumieć należy jako dążenie do osiagnięcia wcześniej wyartykułowanych i uświadomionych celów. Osiągnięcie tych celów (czyt. realizacja interesu grupy) częstokroć możliwe staje się tylko na rynku politycznym, na którym odbywa się dystrybucja reglamentowanych korzyści oraz który konstytuowany jest przez rywalizację. W oczywisty więc sposób na rynku politycznym musi pojawić się konflikt co do sposobu zawłaszczenia określonego dobra politycznego czy té jego dystrybucji. Jest to konflikt interesów politycznych ${ }^{3}$. Podczas takiego konfliktu dochodzi do wypracowania określonego katalogu wartości, poczucia przynależności, odrębności w jednostkach tworzących grupę. Pojawia się więc kategoria grupowego interesu politycznego, którego realizacja w ramach rynku politycznego przez formalny mechanizm decyzyjny może napotkać opór innych grup ${ }^{4}$. Realizacją owego interesu zainteresowane są grupy interesu. Grupy te można zdefiniować jako grupy ludzi zjednoczonych wspólnym, uświadomionym interesem, którzy wykorzystujac posiadane zasoby dqża do powołania struktur organizacyjnych ułatwiajacych promocje oraz realizacje interesu grupowego ${ }^{5}$.

Rekapitulując, grupy interesu starają się wywrzeć wpływ na kierunki polityki państwa, na władzę publiczną w zakresie dystrybucji określonych zasobów, nie sąjednak przy tym zainte-

2 J. Sroka, Grupy interesu w układzie przetargów przemysłowych. Próba oceny możliwości rozwoju nowej perspektywy analitycznej, w: Grypy interesu. Teorie i działanie, red. Z. Machelski, L. Rubisz, Wydawnictwo Adam Marszałek, Toruń 2003, s. 142.

${ }^{3}$ R. Herbut, Interes polityczny jako kategoria politologiczna, w: Studia z teorii polityki, t. 1, red. J. W. Jabłoński, L. Sobkowiak, Wydawnictwo Uniwersytetu Wrocławskiego, Wrocław 1999, s. 55.

${ }^{4}$ Ibidem, s. 55.

${ }^{5}$ J. Sroka, Europejskie stosunki przemysłowe w perspektywie porównawczej, Wydawnictwo Uniwersytetu Wrocławskiego, Wrocław 2000, s. 25. 
resowane zdobyciem, utrzymaniem władzy publicznej czy też przejęciem odpowiedzialności za nią. Poprzestają one jedynie na szeroko rozumianej korekcie politycznego procesu decyzyjnego. Ujawnia się tu pewna dychotomia spojrzenia na owe kwestie. Z jednej strony bowiem można ten wpływ grup interesu rozpatrywać przez pryzmat posiadanych przez nie zasobów, a z drugiej poprzez procesy - działania podejmowane przez grupy interesu.

Wariant pierwszy kieruje nas w stronę czynników decydujących o istnieniu, efektywnym działaniu i rozwoju grupy. Chodzi zatem o te wszystkie zasoby, które znajdują się w dyspozycji organizacji grup interesu, to one bowiem determinują zachowanie - aktywność, powodzenie określonych przedsięwzięć podejmowanych przez grupę interesu. Trzymając się literalnie tematu niniejszego artykułu, postanowiliśmy skupić się na kluczowym z perspektywy lobbingu (w kontekście stosunków przemysłowych) zasobie, jakim jest czynnik merytoryczny. Zaś tych spośród Czytelników, którzy żywo zainteresowani są tematyką zasobów odsyłamy do publikacji J. Sroki poświęconej polityce organizacji pracodawców i przedsiębiorców ${ }^{6}$. Czynnik nas interesujący można inaczej określić mianem czynnika profesjonalnego przygotowania i fachowości. Jego istota sprowadza się do pewnego rodzaju dzielenia się informacją - fachową wiedzą. Otóż współcześnie poziom komplikacji życia społecznego niejako wymusza na agendach administracji publicznej odwoływanie się do wiedzy, doświadczenia i profesjonalizmu grup interesu. Poprzez dość łatwe poruszanie się grup interesu w sferach niepewności administracji publicznej zyskują one możliwość udzielania porad technicznych, przekazywania informacji, przygotowywania ekspertyz. Implikuje to powstanie swoistego układu wymiany, w ramach którego ośrodki władzy otrzymują pomoc przy konstruowaniu określonych rozwiązań, zaś grupy interesu mogą wpływać na kierunki procesu decyzyjnego, którym są one zainteresowane. By jednak możliwy stał się taki scenariusz grupa interesu winna posiadać zaplecze w postaci wiedzy, doświadczenia, struktur organizacyjnych, które pozyskuja, segreguja, przechowuja oraz przekształcaja informacje, a także utrzymuja kontakt $z$ ekspertami $i^{7}$. Znaczenie tego czynnika jest kluczowe dla powodzenia akcji lobbingowej, rozumianej jako proces dostarczania w odpowiednim czasie, miejscu i właściwą drogą informacji, których zadaniem jest legalne ukierunkowanie procesu decyzyjnego. W tym kontekście za główne narzędzie działania można uznać zarządzanie wiedzą ekspercką oraz opracowania merytoryczne ${ }^{8}$.

Gdy zaś chodzi o wymiar aktywności - działań prowadzonych przez organizacje grup interesu, to kluczową w świetle rozważań lobbingowych staje się wspomniana już akcja kolektywna, która może być traktowana jako warunek sine qua non samego lobbingu' ${ }^{9}$ Skoro bowiem prawdziwą jest konkluzja mówiąca o tym, iż lobbing jest pewnym obliczem (strategią prowadzoną w ramach) akcji kolektywnej, to prawdą będzie również to, iż jego istota polega na włączaniu zasobów jednostki lub organizacji w zbiorowe działania, które przekształcić się mają w kolektywne i partykularne korzyści. Choć akcje lobbingowe przynieść mają zysk partykularny ich treść nie może być zupełnie pozbawiona obiektywizmu. Bowiem

\footnotetext{
${ }^{6}$ Zob. szerz.: J. Sroka, Polityka..., op. cit., s. 38-114.

${ }^{7}$ Ibidem, s. 39.

${ }^{8}$ Ibidem, s. 43.

${ }^{9}$ It has, as its general objective, the influencing of decisions made by government authority through information, collective action and other strategies [...]. It is, in part, formal representation in the shape of mandate received from the group on whose behalf the lobbyists operate, and partly informal as these private representatives do not have at their disposal formal channels of communication, nor do they have the institutional recognition enjoyed by elected public officers. L. Graziano, Lobbying, pluralism and democracy, PALGRAVE, Houndmills-Basingstoke-Hampshire-Nowy Jork 2001, s. 1.
} 
jeśli pozbawimy lobbystyczne informacje rzeczowego charakteru to wówczas prawomocna wydawać się będzie teza o pejoratywności tegoż zjawiska, która dość powszechnie rozprzestrzeniła się w krajach Europy Środkowej i Wschodniej. Z drugiej strony warto jednak pamiętać, iż lobbystyczne opracowania zawsze posiadają pewien walor sugestywny. Lobbing, jako „, marketing $w$ duchu makiawelizmu” (Machiavellian marketing), polega w swej istocie na zarzadzaniu informacyjna kampaniq politycznq - zawiera więc pewnq doze manipulacji $i^{10}$.

Jak zauważyliśmy wyżej, sam termin lobbing bywa przedmiotem wielu nieporozumień. By uniknąć tych dylematów autorzy postanowili explicite wyjaśnić czym jest lobbing oraz czym nie jest, a także jakie oblicza przybiera w rzeczywistości społecznej, aby następnie zaprezentować doświadczenia lobbingowe na przykładzie polskich rozwiązań.

Przyjrzyjmy się wybranym formułom definiującym przedmiot nas interesujący. Lobbing, powiedzmy w najszerszym tego słowa znaczeniu, to podejmowanie przez grupy interesu czy też jednostki prób wptywania na treść decyzji władzy państwowej. Chodzi przy tym o wywieranie presji politycznej zarówno na legislatywę i posłów $w$ niej zasiadajacych, jak i agendy administracji publicznej. Lobbing staje się wówczas synonimem grupy interesu ${ }^{11}$. Jego istotę stanowi wpływanie, w ramach określonego porządku prawnego, na decyzje podejmowane przez organy władzy publicznej. ,,International Encyclopaedia of Public Policy and Administration" definiuje lobbing jako stymulowanie i transmisje komunikacji przez ludzi, którzy pragna skutecznie wplynać na procesy decyzyjne w państwie. [...] Ph. Kotler [...] określa lobbing jako , kontaktowanie się i przekonywanie członków ciał ustawodawczych i urzędników państwowych do określonych rozwiazań prawnych i administracyjnych". Natomiast J. Symonds uważa, $\dot{z}$, ,lobbing jest przede wszystkim sposobem promocji idei i spraw. Jest to marketing idei”. Inna definicja przyjmuje, iz rzecznictwo interesów to „,zdolność przekonania decydenta do zrobienia czegoś, czego nie zrobitby bez perswazji lobbysty, lub też do zaniechania czegoś, co normalnie by zrealizowat" "12. W innym ujęciu zauważyć możemy, że lobbing stanowi wspótcześnie odmianę konsultingu, doradztwa prawnego lub politycznego ${ }^{13}$.

W naszym kraju, komplikacja pojęciowa wokół tego zjawiska ponadto jest zwielokrotniona kwestiami lingwistycznymi, a mianowicie brakiem jednoznacznego określenia o czysto polskim rodowodzie. Można się pokusić o próbę znalezienia odpowiednika tej kategorii w języku polskim. Wiemy już, że lobbing stanowi jedną z dróg, dzięki której zainteresowani obywatele i ich stowarzyszenia (często lobbing prowadzą bowiem same stowarzyszenia, co wskazuje na głębokie społeczne zakorzenienie tego zjawiska ${ }^{14}$ ) mogą uczestniczyć w formułowaniu polityki rządu i bronić swoich zagrożonych interesów. Można także stwierdzić, że lobbing to kontaktowanie się i przekonywanie członków organów legislacyjnych oraz urzędników państwowych do wdrażania konkretnych rozwiązań prawnych i administracyjnych. Czy też, że lobbing to aktywność polegająca na dostarczaniu przedstawicielom publicznych ośrodków decyzyjnych niezbędnych informacji, aby mogli oni - możliwie, w pełni świado-

\footnotetext{
${ }^{10}$ J. Sroka, Lobbing w Unii Europejskiej, w: Unia Europejska. Leksykon integracji, red. W. Bokajło, K. Dziubka, Wydawnictwo Europa, Wrocław 2003, s. 337.

${ }^{11}$ Leksykon politologii wraz z Aneksem o: reformie samorzqdowej, wyborach do sejmu, prezydenckich oraz gabinetach rzadowych, red. A. Antoszewski, R. Herbut, Wydawnictwo ATLA 2, Wrocław 2002, s. 213.

${ }^{12}$ K. Jasiecki, M. Molęda-Zdziech, U. Kurczewska, Lobbing. Sztuka skutecznego wywierania wptywu, Wydawnictwo Oficyna Ekonomiczna, Kraków 2006, s. 16.

${ }^{13}$ Cyt. za: K. Jasiecki, Lobbing jako narzędzie biznesu, www.cebi.pl/texty/lobbing.doc, odczyt z dnia 8.04.2010, s. 3.

${ }^{14}$ Not infrequently, lobbying is carried out in the name of associations. This is an important fact, for various reasons. First, it points to the deep-rooted social foundation of the phenomenon... L. Graziano, Lobbying..., op. cit., s. 2.
} 
mie - podejmować określone decyzje. Biorąc więc pod uwagę wymienione „oblicza” lobbingu, w języku ojczystym możemy określić go, jako rzecznictwo interesów lub promowanie pewnych idei $^{15}$.

Podsumowując, powiedzieć wypada, iż lobbing to swoisty sposób kontaktowania się, konsultowania (dialogu) pomiędzy społeczeństwem (grupami interesu) a władzą publiczną. Proces ten przebiega na różnorakich płaszczyznach, w tym również w obszarze stosunków przemysłowych.

Zatem gdybyśmy w tym miejscu zastanowili się nad tym: co właściwie łączy stosunki przemysłowe oraz lobbing, odpowiedź składałaby się z dwóch części. Po pierwsze, powiemy, że obszar stosunków przemysłowych i lobbingową rzeczywistość łączą aktorzy. Otóż, na scenie przemysłowej poruszają się grupy interesu (zwłaszcza wielkie ekonomiczne grupy interesu), zaś lobbing jest w gruncie rzeczy procesem podejmowanym przez te wielkie (choć nie tylko) grupy. Po drugie, praktycznym spoiwem obu kategorii jest ,przedmiot”. Stosunki przemysłowe można potraktować jako pole, na którym ma miejsce partycypacja podmiotów społecznych w procesie sprawowania władzy, partycypacja ta przybiera postać wpływu na decydentów politycznych, odbywa się ona bez wprowadzenia członków grup interesu w formalne struktury administracyjne (polityczne). Lobbing zaś zmierza również do korekty procesu decyzyjnego, takiej korekty, która służyć będzie urzeczywistnieniu interesów grupowych. A zatem można po prostu powiedzieć, że lobbing to swego rodzaju strategia stosunków przemysłowych, która służy realizacji interesu grupowego (w interesującym nas przypadku) w sferze społecznej i gospodarczej. Realizowana jest ona poprzez dostarczenie właściwie przygotowanej informacji poprzez odpowiednie kanały, we właściwym miejscu oraz czasie, tak by informacja ta wywarła właściwy (pożądany przez grupy interesu - lobbystów) wpływ na proces decyzyjny (zob. rysunek 1).

Warto zaznaczyć w tym momencie, że pojęcie lobbingu (rzecznictwa interesów) bywa łączone zazwyczaj ze światem PR, marketingu, komunikacji. Owa predylekcja, zresztą słuszna, wymaga jednak pewnego uzupełnienia. Skoro bowiem pojmujemy lobbing jako proces komunikowania, konsultingu, doradztwa czy też w końcu wywierania wpływu, to czyż nie słusznym jest stwierdzenie, że grupy interesu funkcjonujące w obrębie sceny przemysłowej muszą i/lub chcą wykorzystywać ową strategię. Ostatecznie przecież już nikogo specjalnie nie dziwią różnego rodzaju związki świata pracy czy biznesu z polityką. A zatem jeśli zakładamy, że w ramach stosunków przemysłowych dochodzi do interakcji grup interesu i władzy państwowej, które doprowadzić mogą do wywarcia przez te pierwsze poważnego wpływu na kształt politycznego procesu decyzyjnego, to niejako naturalną implikacją będzie fakt, iż grupy nacisku korzystają na arenie stosunków przemysłowych z różnego rodzaju strategii. Jedną z takich strategii będzie właśnie lobbing. Lobbing, który nakierowany jest (przeciwnie do dialogu społecznego i partnerstwa społecznego) jedynie na partykularne interesy grup nacisku, który daje możliwości takiego kształtowania sytuacji, przedsięwzięć na rynku pracy, które będą zgodne tylko z interesem grupy. Będzie on przy tym atrakcyjny dla podmiotów lobbingujących z racji tego, że jego zastosowanie nie wiąże się z koniecznością wykorzystania wielu zasobów czy też późniejszym ponoszeniem odpowiedzialności za konkretne decyzje i działania, a efekt wpływu może okazać się imponujący. Praktyka pokazuje bowiem, że organizacje partnerów społecznych wykorzystują lobbing, by kształtować odpowiednie

${ }^{15}$ B. Rozwadowska, Public Relations, teoria, praktyka, perspektywy, Wydawnictwo Studio Emka, Warszawa 2002, s. 256. 


\section{Grupa interesu}

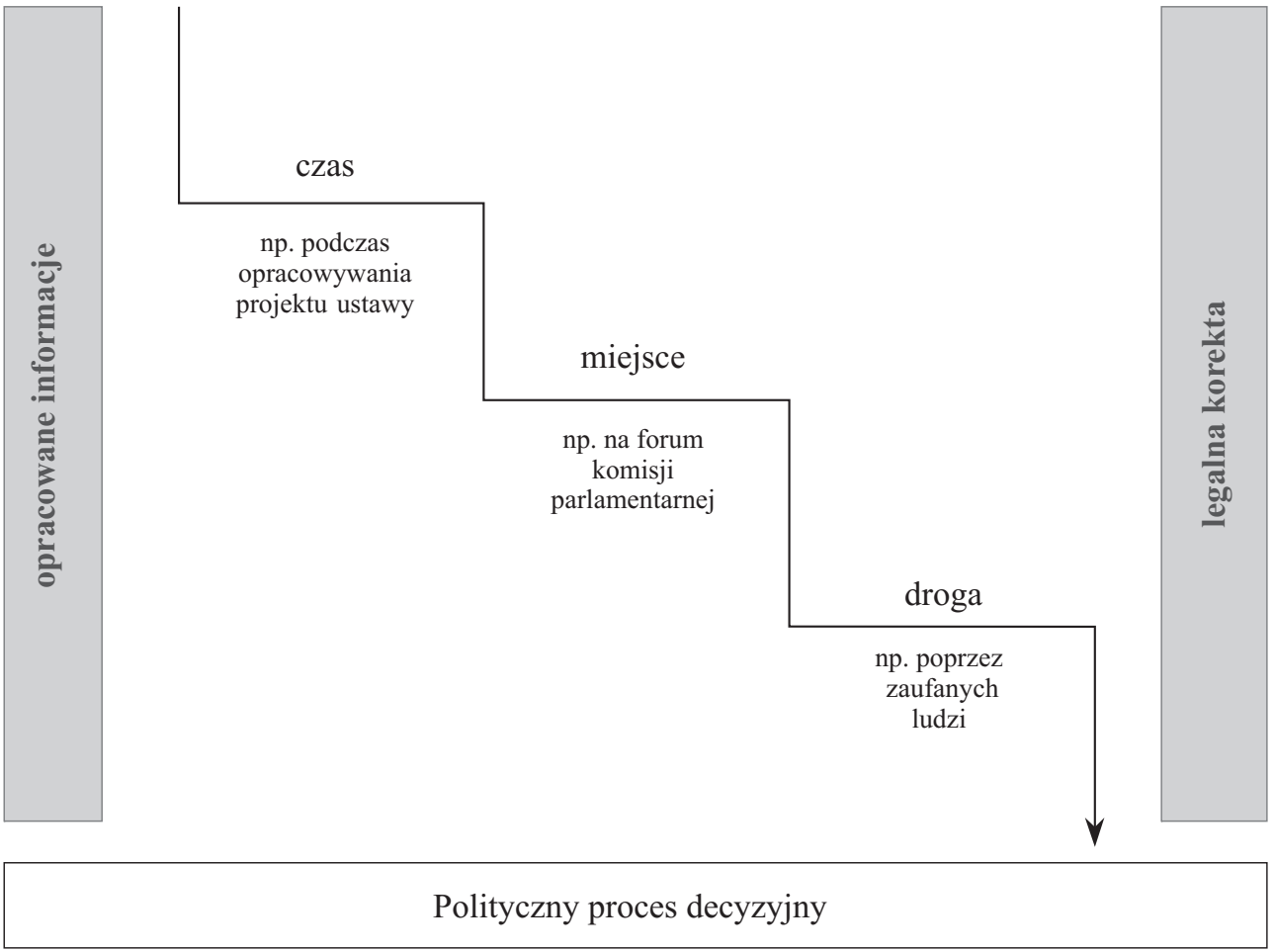

Rys. 1. Lobbing jako proces korekty politycznego procesu decyzyjnego

Źródło: opracowanie własne na podstawie: J. Sroka, Lobbing jako strategia promocji interesów grupowych, w: Marketing polityczny w teorii i praktyce, red. A. W. Jabłoński, L. Sobkowiak, Wydawnictwo Uniwersytetu Wrocławskiego, Wrocław 2002, s. 201-202.

(dla nich) warunki na rynku pracy. Przykładowo określa się wprost, że wśród najważniejszych zadań Maltańskiego Związku Pracodawców (Malta Employers' Association) jest lobbing polityczny na rynku pracy w obszarze zagadnień przynależnych do stosunków przemysłowych oraz bezpieczeństwa socjalnego, a także regularne konsultacje ze związkami zawodowymi, partycypacja w dwu- i trójstronnych instytucjach korporatystycznych, koordynacja przetargów kolektywnych, opracowywanie (wnioskowanie) obowiązujących porozumien $^{16}$.

Konkludując, powiemy, że lobbing stanowi pewnego rodzaju ujście, kanał stosunków przemysłowych, czy też może precyzyjniej rzecz ujmując, że lobbing to materializacja stosunków przemysłowych, jedna z dróg ich realizacji, a jej specyfiką jest operowanie informacją tak, by decydent podjął lub zaniechał podjęcia określonej decyzji. Być może warto, z pobudek semantycznych, wprowadzić pojęcie lobbingu industrialnego, czyli takiego który swój początek

\footnotetext{
${ }^{16}$ M. Debono, Employers' organisations examined, http://www.eurofound.europa.eu/eiro/2003/10/feature/
} mt0310101f.htm, odczyt z dnia 08.04.2010. 
bierze z przetargu interesów przemysłowych, toczy się w jego otoczeniu, kojarzony jest wprost z działalnością lobbingową świata pracy i kapitału (zob. rysunek 2).
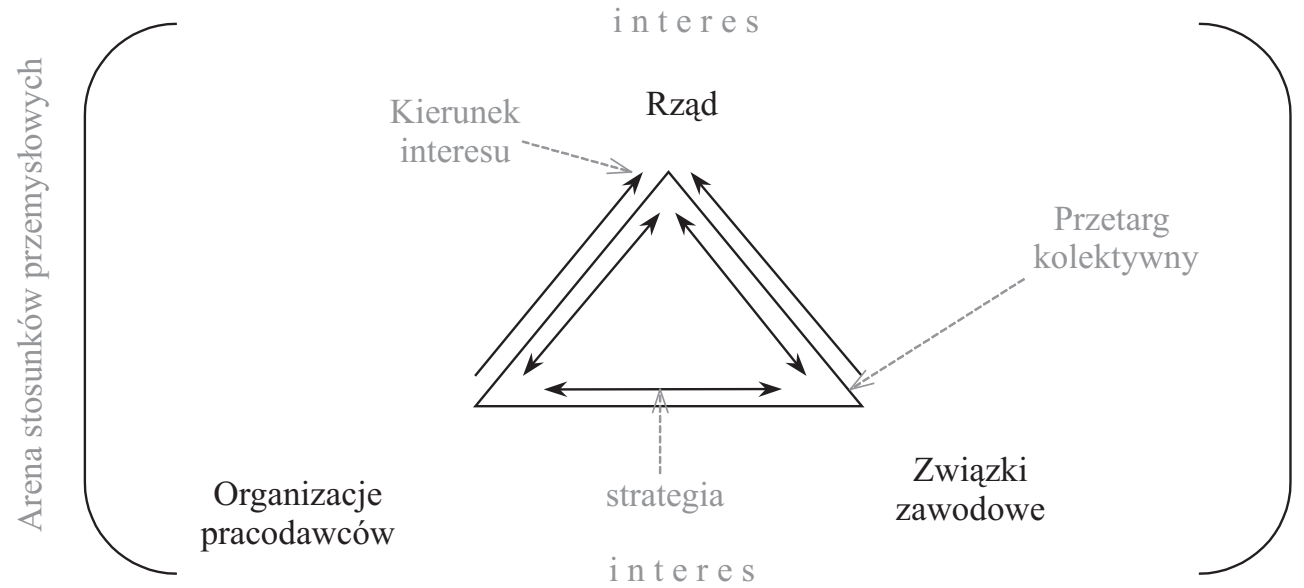

Legenda: strzałki oznaczają strategie stosowane przez wybrany podmiot. Strzałki zakończone podwójnym grotem $(\longleftrightarrow$ ) wskazują na strategie z przewagą komunikacji dwukierunkowej, w ramach których przetarg kolektywny odnosi się nie tylko do interesów partykularnych, ale także do interesów ogólnospołecznych. Oznacza to, że organizacje grup interesu, wykorzystując te strategie, muszą uwzględniać nie tylko swoje własne interesy, ale także interes innych grup/interes ogólnospołeczny. Strzałki zakończone jednym grotem $(\longrightarrow)$ informują o strategiach jednokierunkowych, w ramach których realizowany jest jedynie interes grupy. Wpływ wywierany za pomocą tych strategii skierowany jest na ośrodki władzy publicznej, tak by w ten sposób umożliwić realizację oczekiwań grupy. Wśród tych ostatnich strategii znajduje się lobbing, będący w gruncie rzeczy strategią o przewadze komunikacji jednokierunkowej, poprzez którą można w łatwy sposób przekazać odpowiednią informację od elit grup interesu do politycznych decydentów.

Rys. 2. Lobbing jako składowa stosunków przemysłowych

Źródło: Opracowanie własne w oparciu o rysunek 2.I A Model of Triangular Bargaining for the Public Sector, w: T. Hastings, Politics, Management and Industrial Relations, Semi-State Companies and the Challenges of Marketization, Blackhall Publishing, Dublin 2003, s. 18 oraz z uwzględnieniem informacji z tabeli 3. Wiodące różnice pomiędzy podstawowymi rodzajami organizacyjnych strategii grup interesu wobec politycznych kręgów decyzyjnych, w: J. Sroka, Lobbing..., op. cit., s. 218, 219.

Zachodzi tu pewna prawidłowość w odniesieniu do modeli stosunków przemysłowych, jakie występują w danym państwie. Rzecz bowiem w tym, że natężenie wykorzystania strategii lobbingowych jest znacznie wyższe w przypadku ,państw pluralistycznych” aniżeli w przypadku korporatystycznych ${ }^{17}$. Przyczyną takiej sytuacji jest fakt, iż grupy interesu poruszające się w przestrzeni korporatystycznej zwykle posiadają stały, zagwarantowany wpływ na przebieg politycznego procesu decyzyjnego. Dzieje się tak z dwóch podstawowych przyczyn.

${ }^{17}$ Pluralizm oraz korporatyzm stanowią dwa modele relacji przebiegających pomiędzy państwem a grupami interesu (modele stosunków przemysłowych). W rzeczywistości te dwie formy mocno się przeplatają, niemniej jednak można w teorii wyróżnić katalog cech właściwych tym dwóm wzorcom. I tak, korporatyzm wiązany będzie silnie z koordynacją, centralizacją przetargów, hermetycznością gremiów decyzyjnych, jasno określonym katalogiem spraw podlegających negocjacjom czy też szeroką agregacją interesów. Zaś pluralistyczna wizja przywodzi na myśl wolnorynkowe zasady gry, brak monopolizacji reprezentacji interesów grupowych, decentralizację, ciagłe przetargi $\mathrm{z}$ dominacją rywalizacji. 
Po pierwsze, [...] organizacje afiliowane w strukturach trójstronnych nie maja zwykle potrzeby sięgania po lobbing, którego wykorzystanie wiąze się przecież z potrzeba poniesienia dodatkowych kosztów.

Po drugie, wykorzystanie lobbingu przez organizacje, których przedstawiciele zasiadaja do stołu negocjacyjnego z reprezentantami władzy i innych grup interesu, mogłoby narazić je $n a[\ldots]$ utrate reputacji oraz zaufania ze strony pozostatych stron dialogu ${ }^{18}$.

Do wymienionych przyczyn dodajmy jeszcze problem związany z rodzajem i charakterem grup interesu pojawiających się na scenie przemysłowej. Kwestia, jakie to będą ciała, jest wprost proporcjonalna do charakteru funkcjonującego rynku politycznego. W sytuacji, gdy mamy do czynienia z całkowitą otwartością rynku politycznego pojawią się na nim jednocześnie partie polityczne, organizacje grup interesu, ruchy społeczne, wyspecjalizowane firmy lobbingowe oraz indywidualni lobbyści. Praktyka jednakże pokazuje, iż nawet w najbardziej liberalnych (pluralistycznych) systemach politycznych pojawiają się obostrzenia, mające za zadanie ,domknięcie” rynku politycznego w kierunku oligopolu, a nawet monopolu w najczystszej postaci. Wówczas to struktura ciał lobbingujących ulega spłaszczeniu, a ich liczba szybko maleje. Niewątpliwie, partii politycznych, jak i organizacji grup interesu będzie na rynku niewiele, jednakże te istniejące pozostawać będą w dużo bardziej komfortowej sytuacji ze względu na swą dominującą rolę oraz brak relewantnej (pod względem profilu działalności) konkurencji. Firmy lobbingowe będą funkcjonować na skraju opłacalności, co może spowodować ich kompletny zanik. Podobnież stanie się z organizacjami społecznymi, które napotkawszy na zbyt wielkie - posługując się terminologią menadżerską - bariery wejścia nie będą w stanie spełnić swej roli. W takim otoczeniu nawet najsłabszej reprezentacji swych interesów nie zdołają wygenerować grupy pozostające w mniejszości. Z drugiej strony, na takim rynku skorzystają podmioty o trochę innym charakterze (np. monopolistyczne czy też quasi-monopolistyczne zakłady przemysłowe lub też prywatni lobbyści działający na pograniczu „,szarej strefy”), które zagospodarują zadania ,,agentów artykulacji”, występując jedynie w imieniu swych członków ${ }^{19}$.

W kontekście rynku, a w szczególności systemu politycznego (tym samym modelu stosunków przemysłowych), lobbing pełni również zdecydowanie odmienne funkcje, a u jego podwalin leżą inne przyczyny. Należy podkreślić, iż staje się on integralną częścią systemu legislacyjnego, ale przede wszystkim w systemie politycznym opartym o pluralistyczny model stosunków przemysłowych. W Polsce, o której, mimo wszystko, trudno byłoby mówić jako o systemie pluralistycznym (a nawet skonsolidowanej demokracji), zjawisko to pojawia się na niezwykle płynnej granicy biznesu i polityki. Nie byłoby w tym nic zdrożnego, gdyby nie fakt, iż tym kontaktom brakuje jednocześnie jasnych i społecznie usankcjonowanych kryteriów, gdzie kończy się artykułowanie i rzecznictwo interesów, a zaczyna się,,załatwianie". Wraz z odejściem poprzedniego systemu politycznego, w kraju mamy do czynienia ze swoistym chaosem normatywnym, w którym próżno by doszukiwać się ogólnie przyjętych regulatorów funkcjonowania instytucji i stosunków międzyludzkich (takim regulatorem z pewnością nie stanie się obowiązująca ustawa o działalności lobbingowej w procesie stanowienia prawa, przynajmniej w jej obecnym kształcie). Truizmem będzie w tym miejscu stwierdzenie, że taki ustrój normatywny wykształca się ${ }^{20}$ dopiero wraz z rozwojem

\footnotetext{
${ }^{18}$ J. Sroka, Polityka..., op. cit., s. 43.

${ }^{19}$ Ibidem, s. 195.

${ }^{20}$ Pewne działania zostały już podjęte w 2003 r. wraz z powstaniem Polskiego Stowarzyszenia Profesjonalnych Lobbystów oraz przyjętego przez tą organizację Kodeksu etyki zawodowej lobbystów.
} 
społeczeństwa obywatelskiego i wszelkich norm życia społeczno-politycznego, jakie się z nim wiążą.

Zważywszy na powyższe konkluzje, niebezzasadnie, powiemy, że lobbing stanowi immanentną cechę stosunków przemysłowych i jego wykorzystanie właściwie nie powinno nikogo specjalnie dziwić. Sęk jednak w tym, że pomimo tego wciąż zbyt mało o nim wiadomo opinii publicznej, która (zwłaszcza w krajach Europy Środkowej i Wschodniej) postrzega go w sposób jednoznacznie negatywny. Przyczyn tego stanu rzeczy upatrywać można bądź to w etycznej dwuznaczności (niejasności) tego pojęcia, bądź to w określaniu mianem lobbingu tych przedsięwzięć, które de facto nim nie są.

\section{Rzecz o empirii}

Jak już podkreślaliśmy, w krajach naszego regionu, działania lobbingowe nie cieszą się społeczną aprobatą (lub w najlepszym wypadku przyjmowane są ambiwalentnie). Fakt ten nie powinien nikogo specjalnie dziwić. Jeśli bowiem przyjrzymy się innym formom uczestnictwa obywateli w życiu publicznym, to również ujawnią się w tym względzie poważne braki. Z jednej strony można taki stan rzeczy tłumaczyć ,,przyzwyczajeniami” wyniesionymi z systemu realnosocjalistycznego, a z drugiej, poważną niechęcią czy też nierozumieniem zasad partycypacji. W przypadku interesującego nas lobbingu, sprawę komplikuje niejasność terminologiczna, synonimiczne traktowanie go z czymś nielegalnym, nieformalnym, nieetycznym, tajemniczym. Polski lobbing, również naznaczony piętnem dwuznaczności, realizowany jest przez organizacje grup interesu ,przy pomocy” parakoalicji z partiami politycznymi lub za sprawą instytucji negocjacyjnych. Wypada tu jednak zauważyć, iż gros lobbingowych działań wielkich sekcjonalnych grup interesu nie odbywa się już za pośrednictwem instytucji trójstronnych (patrz tabela 1). Pojawiają się bowiem nowe formuły na sprawną artykulację interesów, inne tradycyjne ścieżki dotarcia do procesu decyzyjnego są mniej lub bardziej efektywnie wykorzystywane, intensyfikuje się działalność lobbingowa konkurujących o uwagę sekcjonalnych organizacji interesu, ujawnia się użyteczność kampanii profesjonalnych firm z dziedziny Public Affairs, a także coraz częściej - w szczególności w ramach demokracji deliberacyjnej $^{21}$ - to sam proces decyzyjny wychodzi im naprzeciw.

Nie dziwi zatem fakt, iż lobbing realizowany jest przy pomocy rozmaitych metod, form i środków. Niewątpliwie nie ogranicza się on wyłącznie do prowadzenia ,nacisku kongresowego" na legislację (patrz tabela 1). Profesjonalny lobbing najpełniej rozwinięty jest obecnie w Stanach Zjednoczonych, do którego polskim rozwiązaniom lobbystycznym jeszcze daleko, pomimo uregulowania tej sfery odpowiednią ustawą ${ }^{22}$. W kontekście naszych rozważań „dość interesująco" działalność lobbingowa wygląda właśnie w świetle wspomnianej ustawy o działalności lobbingowej w procesie stanowienia prawa. W myśl art. 2 działalność lobbingowa określona jest jako: każde działanie prowadzone metodami prawnie dozwolonymi zmierzajace do wywarcia wplywu na organy władzy publicznej w procesie stanowienia prawa. Taka konstrukcja definicyjna w ustawie stanowi podstawę do krytyki tegoż aktu. Nie mamy

\footnotetext{
${ }^{21}$ Na temat polityki deliberacyjnej zobacz m.in.: Wybrane instytucje demokracji partycypacyjnej w Polskim systemie politycznym, red. J. Sroka, Wydawnictwo Instytut Pracy i Spraw Socjalnych, Warszawa 2008; J. Sroka, Deliberacja i rzadzenie wielopasmowe. Teoria i praktyka, Wydawnictwo Uniwersytetu Wrocławskiego, Wrocław 2009.

${ }^{22}$ Ustawa z dnia 7 lipca 2005 roku o działalności lobbingowej w procesie stanowienia prawa, Dz. U. 2005, Nr 169, poz. 1414 .
} 


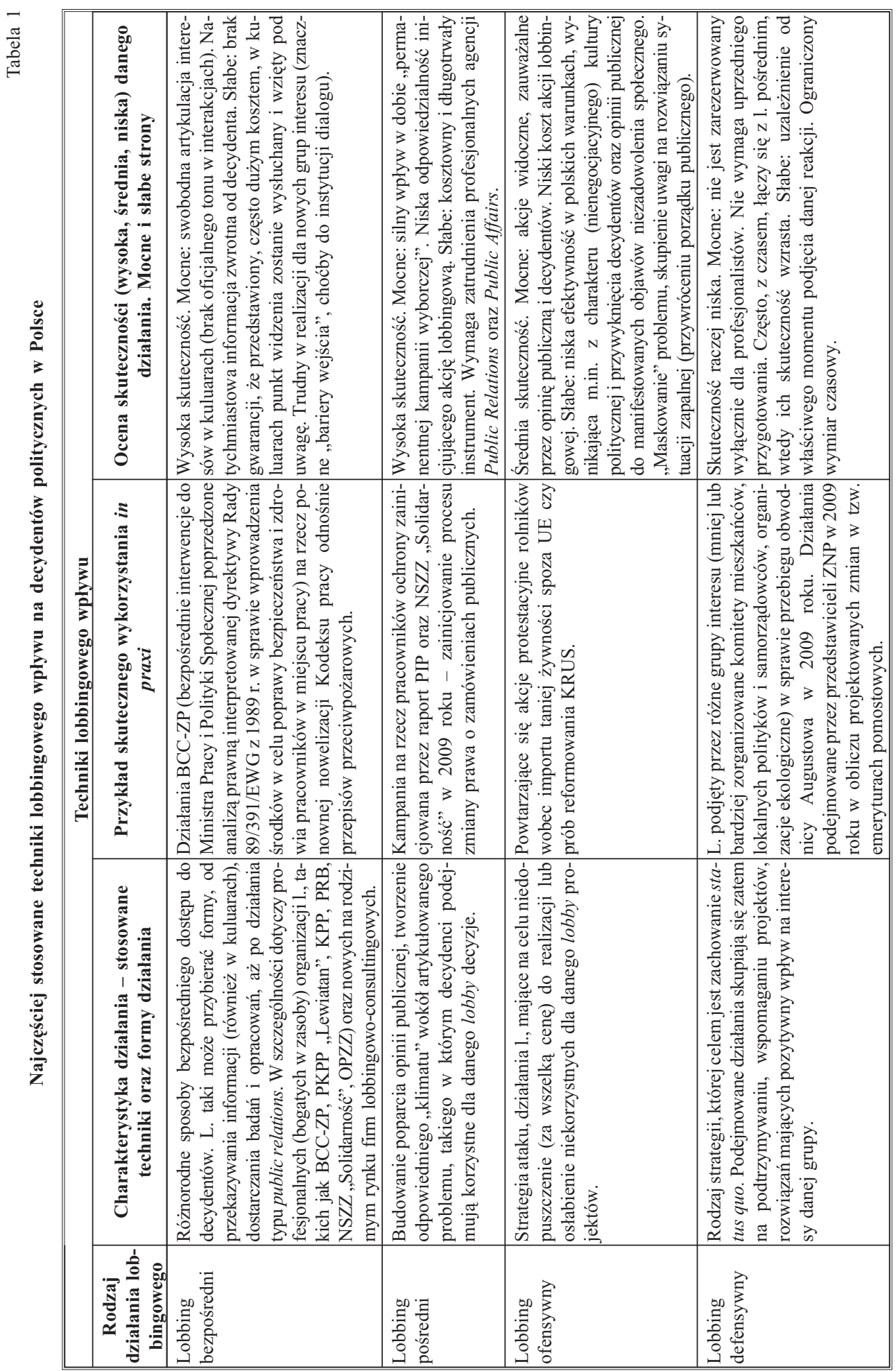




\begin{tabular}{|c|c|c|c|c|c|}
\hline & 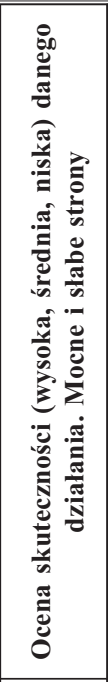 & 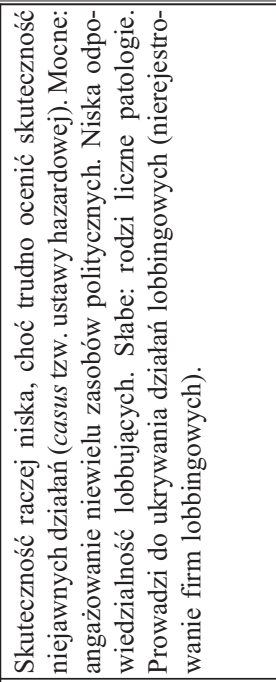 & 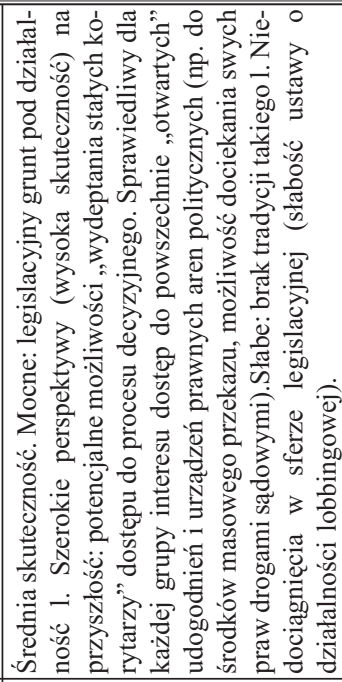 & 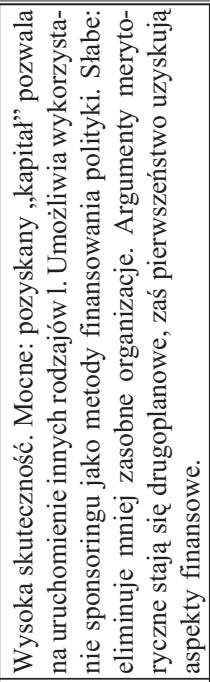 & 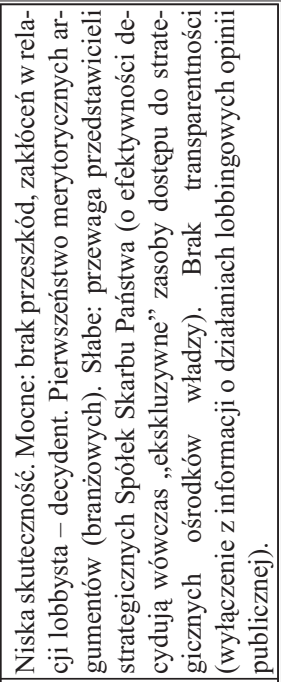 \\
\hline & 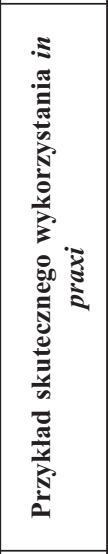 & 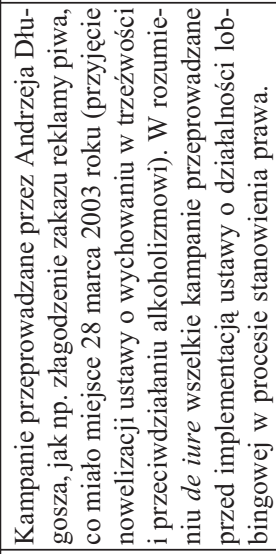 & 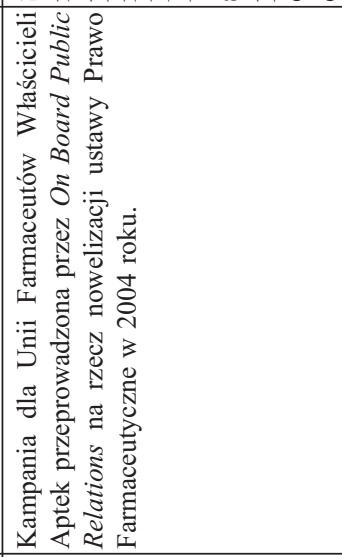 & 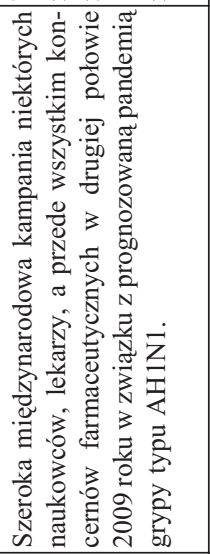 & 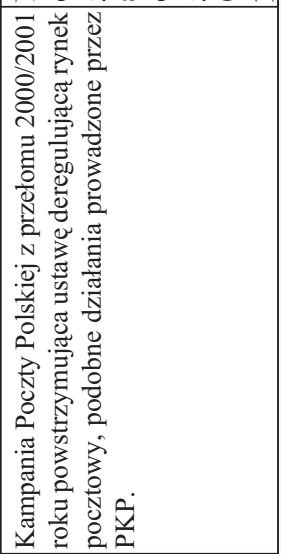 \\
\hline & 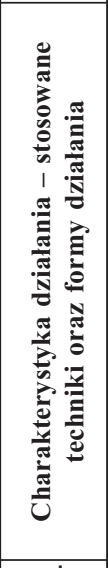 & 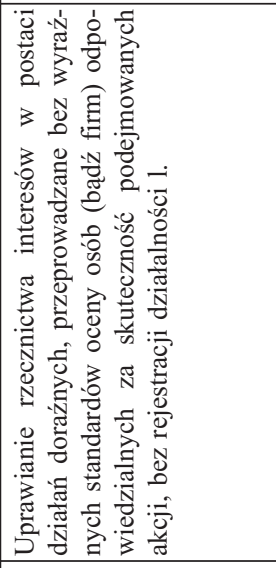 & 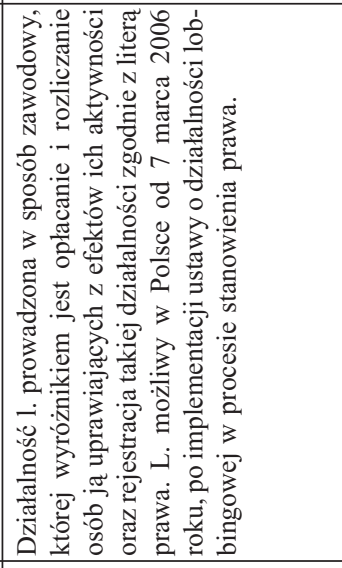 & 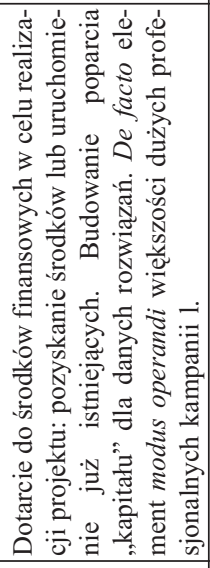 & 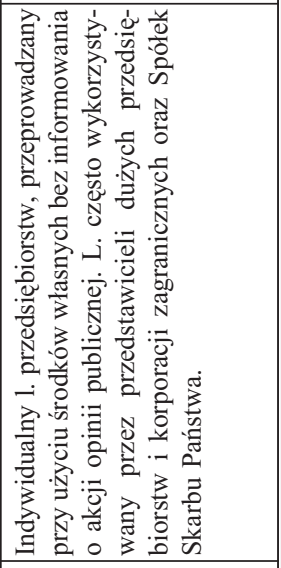 \\
\hline & 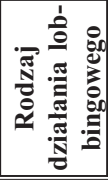 & & 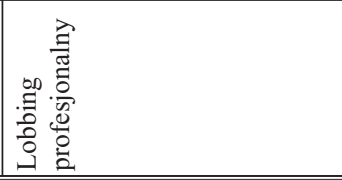 & : & 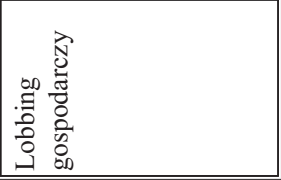 \\
\hline
\end{tabular}




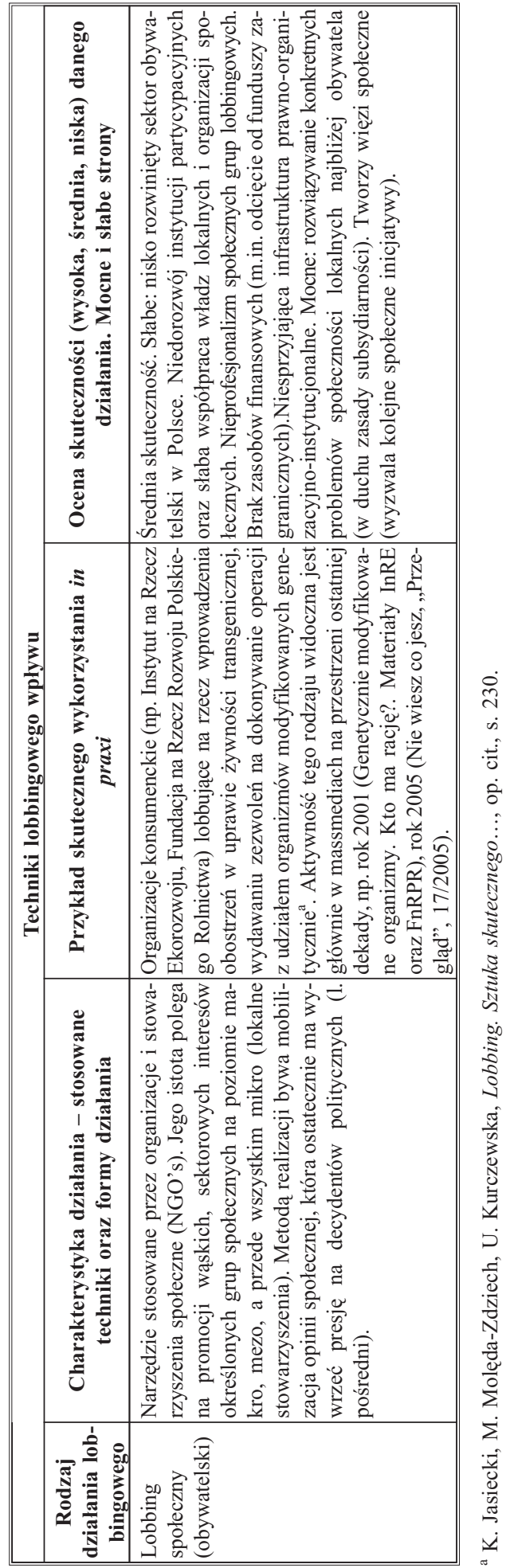


tutaj miejsca na gruntowną analizę polskiej ustawy, skoncentrujemy się jedynie na kilku istotnych dla naszych rozważań, a płynących z jej lektury, wnioskach dla systemu stosunków przemysłowych oraz najważniejszych zarzutach pod jej adresem, jakie możemy wystosować na podstawie prawie czterech lat, które upłynęły od implementacji ${ }^{23}$.

Definicja zaprezentowana w ustawie jest co najmniej nieprecyzyjna. Zgodnie z zaprezentowanym wyżej, przyznać należy, bardzo szerokim rozumieniem za działalność lobbingową moglibyśmy uznać także wszelkie kontakty przedstawicieli administracji publicznej realizowane w ramach dialogu społecznego, dotychczasowych konsultacji społecznych, a nawet korporacyjnych instytucji trójstronnych czy gwarantowanego konstytucyjnie obywatelskiego prawa do petycji. Z drugiej strony jednak, jedyną przewidzianą de iure formą działalności lobbingowej jest zawodowa (zarobkowa) działalność, prowadzona na rzecz osób trzecich, w celu uwzględnienia w procesie stanowienia prawa interesów tych osób. Może ją prowadzić wyłącznie przedsiębiorca lub osoba fizyczna niebędąca przedsiębiorcą na podstawie umowy cywilnoprawnej $^{24}$, co powoduje znaczne okrojenie lobbingowego rynku (np. o stosunkowo najaktywniejsze lobbingowo, przynajmniej w ostatnich latach, organizacje pracodawców i pracobiorców), wbrew dotychczasowym doświadczeniom i praktyce.

Kolejnym podnoszonym problemem ustawy, a tym samym polskiego lobbingu jest jego niedookreślenie - fragmentaryczne, wycinkowe traktowanie lobbingu jako działalności wyłącznie w sferze dotyczącej stanowienia prawa (a konkretniej: projektów ustaw i rozporządzeń). Przypomnijmy tylko, iż lobbing dotyczy całokształtu wpływania na procesy decyzyjne w państwie - powinien być więc pojmowany znacznie szerzej niż tylko w odniesieniu do tworzenia i wydawania aktów normatywnych. Poza zainteresowaniem ustawy pozostają natomiast kwestie przygotowywania projektów ustaw przez grupy obywateli oraz Sejm i Senat, czyli komisje i grupy posłów czy senatorów, a także ustaw i rozporządzeń przygotowywanych przez Prezydenta RP oraz innych aktów normatywnych, np. Krajowej Rady Radiofonii i Telewizji. Ustawa nie reguluje również stanowienia - najbardziej ważkiego dla obywatela - prawa miejscowego.

W założeniu autorów w ustawie miały dominować atrybuty jawności stanowienia prawa i działalności lobbingowej. Znajdujemy tu oczywiście przesłanki takiej transparentności. Każdorazowo lobbysta, po złożeniu drogą formalną specjalnego zgłoszenia $\mathrm{z}$ danymi o sobie i zleceniodawcach, może przystąić do prac nad danym aktem prawnym na zasadach tzw. wysłuchania publicznego. Niestety, jest to kolejny nie do końca zdefiniowany element tej krótkiej, bo składającej się jedynie z 19 merytorycznych artykułów ustawy. Po pierwsze, urzędnik ma prawo w niektórych przypadkach odwołać takie wysłuchanie na podstawie jedynie sobie znanych kryteriów (ustawa ich nie wymienia). Po drugie, nie dostaje on sugestii od ustawodawcy, jak traktować i współpracować z potencjalnym lobbystą. Podobnych wzorców niestety brakuje do dzisiaj ${ }^{25}$ (co objawia się w działalności niektórych komisji sejmowych,

\footnotetext{
${ }^{23}$ Ustawa o działalności lobbingowej w procesie stanowienia prawa weszła w życie po upływie sześciu miesięcy od dnia ogłoszenia (Dz. U. z dnia 6 września 2005 r.).

${ }^{24}$ Ustawa z dnia 7 lipca 2005 r. o działalności..., op. cit., art. 2, ust. 3.

${ }^{25}$ Ministerstwo Spraw Wewnętrznych i Administracji zgodnie z zadaniami nałożonymi na nie w Strategii Antykorupcyjnej dokonuje co roku przeglądu stanu realizacji zapisów tzw. ustawy lobbingowej przez ministerstwa oraz Kancelarię Premiera Rady Ministrów (pierwszy raport z wykonania ustawy zatytułowany „Raport na temat lobbingu" został przygotowany przez Departament Administracji Publicznej i Departament Prawny MSWiA w styczniu 2007 roku). W raporcie za rok 2006 wykazano, że wiele ministerstw, w tym Ministerstwo Sprawiedliwości w ciągu 10 miesięcy obowiązywania ustawy nie zdążyło przygotować specjalnych procedur zwiazanych z lobbingiem (s. 14-18).
} 
o czym niżej) i pozwala to nam wysnuć hipotezę, iż na podstawie dotychczasowych efemerycznych zapisów nie powstaną żadne ustandaryzowane kryteria w tym zakresie, a współpraca z lobbystą zależeć będzie od czynników nieobiektywnych, odmiennych w każdym urzędzie.

Wspomniana transparentność lobbingowych kontaktów wynikająca z ustawy opiera się na obowiązku niezwłocznego informowania przez organy władzy publicznej poprzez „Biuletyn Informacji Publicznej" o wszelkich działaniach podejmowanych wobec nich przez grupy nacisku wraz z zaznaczeniem pożądanego przez nie sposobu rozstrzygnięcia danej kwestii. Taki obowiązek, mający w założeniu walczyć z zachowaniami korupcjogennymi, traci swe zalety w przypadku, gdy staje się on obligatoryjny jedynie dla jednej ze stron przetargu interesów. Tak jest niestety w przypadku omawianej ustawy.

Innym problemem o podobnym zakresie oddziaływania jest penitencjarność przepisów odnoszących się do lobbystów (szereg sankcji o charakterze administracyjnym na karze pieniężnej w wysokości 50000 złotych skończywszy) oraz brak obiektywnych zachęt dla osób prawnych bądź fizycznych parających się lobbingiem przed wejściem w życie ustawy do zarejestrowania się jako zawodowi lobbyści po jej implementacji. Od początku prac nad tą ustawą wywoływało to naukowe kontrowersje ${ }^{26}$, przywoływano negatywne doświadczenia ustawy litewskiej ${ }^{27}$. Jak możemy ocenić tę sytuację po czteroletnim obowiązywaniu polskiej ustawy? Na dzień 7 kwietnia 2010 r. wpis do prowadzonego przez Ministerstwo Spraw Wewnętrznych i Administracji Rejestru Podmiotów Wykonujących Zawodową Działalność Lobbingową ${ }^{28}$ uzyskało 164 organizacje (w tym indywidualni lobbyści, firmy consultingowo-lobbingowe, kancelarie prawnicze, kilka stowarzyszeń i izb branżowych etc. $)^{29}$. Nie jest to oczywiście lista zamknięta, jednakże dane pokazują, iż najwięcej lobbystów zarejestrowało się w ciągu pierwszego półrocza od zapoczątkowania rejestru ${ }^{30}$, w następnych miesiącach rejestrowało się i rejestruje średnio 3-4 nowych lobbystów w miesiącu. Należy przypuszczać niestety, że prawdziwy lobbing toczy się nadal poza rejestrem i regułami ustawy. Świadczą o tym nie tylko liczba zarejestrowanych lobbystów, lecz także wymienione wyżej ograniczenia ustawy, jak również badania przeprowadzone przez Fundację im. Stefana Batorego. Fundacja monitorowała w ośmiu komisjach sejmowych różnorodne ustawy w ramach programu przeciwko korupcji. Jak się okazało, lobbyści nie byli zainteresowani udziałem w komisjach sejmowych - w żadnej z komisji nie było oficjalnie lobbystów ${ }^{31}$. Inne

\footnotetext{
${ }^{26}$ Zob. np.: K. Jasiecki, Lobbing po Polsku, „Biuletyn Dialogu Społecznego” 2005, nr 9, s. 5-7; „Lobbing i działalność rzecznicza organizacji pozarządowych w świetle nowych regulacji prawnych”, seminarium zorganizowane 10 stycznia 2006 r. przez ISP i Fundację im. Stefana Batorego. Zapis przebiegu seminarium dostępny jest na stronie Fundacji im. Stefana Batorego pod adresem: http://www.batory.org.pl/korupcja/aktual.htm; M. Zubik, Ustawa o działalności lobbingowej w procesie stanowienia prawa. Uwagi na tle sytuacji organizacji pozarzadowych, http://www.batory.org.pl/korupcja/aktual.htm; M. Dobranowska-Wittels, Lobbing, nie lobbing...?, gazeta.ngo.pl 2006, nr 2 (26).

${ }^{27} \mathrm{Na}$ Litwie po uchwaleniu ustawy o działalności lobbystycznej, co miało miejsce 27 czerwca 2000 roku (ustawa weszła w życie 1 stycznia 2001 roku) w ciągu półtora roku zarejestrowanych zostało tylko sześciu lobbystów i jedno stowarzyszenie, reszta zaś nie chciała się ujawnić.

${ }^{28}$ Podstawa prawna: art. 10 ust. 2 ustawy o działalności lobbingowej w..., op. cit.

${ }^{29}$ Zob.: Rejestr Podmiotów Wykonujących Zawodową Działalność Lobbingową, Kancelaria Sejmu.

${ }^{30}$ Co nastąpiło na podstawie Rozporządzenia Ministra Spraw Wewnętrznych i Administracji z dnia 20 lutego 2006 r. w sprawie rejestru podmiotów wykonujacych zawodowq działalność lobbingowa (Dz. U. 2006, Nr 34, poz. 240). Pierwszy wpis w Rejestrze pochodzi z 14 marca 2006 roku.

${ }^{31}$ Zob. Raport z realizacji projektu ,, Monitoring Procesu Stanowienia Prawa w 2006 roku”, Fundacja im. Stefana Batorego, Warszawa 2007; Raport z realizacji projektu „, Monitoring Procesu Stanowienia Prawa w 2007 roku”, Fundacja im. Stefana Batorego, Warszawa 2008. Por. Raport z realizacji projektu ,Monitoring Procesu Stanowienia Prawa w 2008 roku”, Fundacja im. Stefana Batorego, Warszawa 2009.
} 
badanie Fundacji im. Stefana Batorego pokazało z kolei problem udziału w pracach komisji sejmowych gości, traktowanych jako ekspertów. Co więcej, uwagi zgłaszane przez gości byty przedstawiane przez przekonanych postów jako ich własne poprawki i następnie przegłosowywane. Biuro legislacyjne Sejmu uznało taka procedure za właściwa ${ }^{32}$. Wskazują na to również sejmowe stenogramy wielu komisji sejmowych, m.in. komisji „Przyjazne Państwo”, w obradach której w 2008 roku aktywnie uczestniczył - przygotowując nawet kompletny projekt ustawy o odpadach medycznych - niezarejestrowany jako lobbysta przedstawiciel organizacji pozarządowych walczących z dioksynami, a jednocześnie prywatny przedsiębiorca (właściciel firmy, która na przygotowywanych rozwiązaniach zyskałaby finansowo) ${ }^{33}$. Problem ukrywania się lobbystów „pod szyldem” organizacji pozarządowych nie ogranicza się wyłącznie do komisji sejmowych czy senackich. Sięga zdecydowanie wyższych szczebli. Tego typu patologiczne zachowania pokazały nawet obrady Komitetu Stałego Rady Ministrów, w szczególności podczas prac nad nowelizacją ustawy o grach losowych, zakładach wzajemnych i grach na automatach w 2009 roku $^{34}$.

Rekapitulując rozważania poświęcone praktyce polskiego lobbingu wobec rozwiązań ustawy o działalności lobbingowej w procesie stanowienia prawa można pokusić się o komentarz, iż ta ustawa tą działalność efektywnie wygasza - przynajmniej jeśli chodzi o jawny lobbing - a na pewno nie wspiera polskich stosunków przemysłowych. Wymienione wyżej i pokrótce opisane wybrane merytoryczne błędy ustawy jak: fiksacja wyłącznie na poziomie Rady Ministrów i Sejmu (brak odwołań do innych instytucji prawodawczych w systemie politycznym), wprowadzenie wymogu informowania o lobbingowych kontaktach jedynie przedstawicieli urzędów obsługujących organy administracji publicznej czy wreszcie nieuzasadnione sięganie po instytucję dialogu społecznego jako narzędzie uprawiania lobbingu etc. sprawiają, że lobbing będzie nadal się dezawuował i już niedługo będziemy mogli badać z całą naukową powagą ,szarą strefę” lobbingu w Polsce. Słabość legislacji nie wpłynie również pozytywnie na ukonstytuowanie się polskiego modelu stosunków przemysłowych, którego częścią działalność lobbingowa niewątpliwie jest. Być może jednak te negatywne tendencje zdoła odwrócić nowa, przygotowywana aktualnie ustawa o lobbingu, która według zapowiedzi ma być aktem prawnym zdecydowanie bardziej powiązanym z rzeczywistością lobbingu w Polsce ${ }^{35}$.

${ }^{32}$ Raport z realizacji projektu „, Monitoring Procesu..., op. cit., s. 7.

${ }^{33}$ Sprawę odkryli dziennikarze śledczy TVP.INFO. Posłowie komisji „Przyjazne Państwo” w marcu 2008 roku w ekspresowym tempie, bez dyskusji i konsultacji społecznych, przyjęli ustawę o odpadach medycznych przygotowaną przez Arkadiusza Tułeckiego, przedsiębiorcę, który podawał się przed komisją za przedstawiciela dwóch organizacji pozarządowych: Stowarzyszenia Bez Dioksyn oraz Stowarzyszenia na Rzecz Rozwoju i Stosowania Bezdioksynowych Technologii Unieszkodliwiania Niebezpiecznych Odpadów Medycznych. Nie zarejestrował się on na liście sejmowych lobbystów, gdyż jak twierdził w późniejszych wywiadach prasowych: Nie spetniam odpowiednich kryteriów. Zostałem zobligowany przez moje stowarzyszenie do zaproponowania projektu tej ustawy $i$ nic ponad to. Dzięki ustawie zezwalającej na alternatywną do spalania formę neutralizacji odpadów medycznych firma lobbysty mogła osiągnąć wysokie zyski, sterylizując odpady medyczne. Według opinii rządowych ekspertów, nowe przepisy mogły być groźne dla środowiska naturalnego. Na ten temat zob. m.in.: V. Kuźniewska, Puścili ustawe przez komin, „Gazeta Polska” 2009, nr 39, s. 4-5; Ł. Marcinkiewicz, Lobbing w „Przyjaznym Państwie”, „Rzeczpospolita" (W3) 2009, nr 25, s. A15, http://wiadomosci.wp.pl/kat,1355,title,Lobbysta-napisal-dla-Palikota-niebezpieczna-ustawe, wid, 10943542, wiadomosc.html.

${ }^{34}$ Ujawnione kontakty lobbystów z przedstawicielami Komitetu Stałego Rady Ministrów w 2009 roku zrodziły tzw. ,,aferę hazardową”. Na ten temat zob. m.in. I. Ryciak, K. Szczepaniak, Państwo w szponach hazardu, „Przekrój” 2009, nr 41; M. Czarkowski, Krajobraz po ustawie, „Przegląd” 2009, nr 48, s. 14-15.

${ }^{35}$ Zupełnie nową ustawę o działalności lobbingowej przygotowują jednocześnie dwa środowiska polityczne. W czwartym kwartale 2009 roku prace nad aktem prawnym rozpoczęło PiS, nawiązując merytoryczną współpracę 


\section{Podsumowanie}

Lobbing traktowany jako strategia organizacji grup interesu nie powinien wzbudzać żadnych kontrowersji. Winien on być raczej traktowany jako ,naturalne” narzędzie realizacji interesów grupowych. Niestety, jak na razie, nie zapowiada się w tym względzie poważna zmiana mentalnościowa społeczeństw wschodnioeuropejskich, a nawet zauważalnym pozostaje wręcz przeciwny proces. Systematycznie media „bombardują" nas licznymi doniesieniami o skandalicznych akcjach lobbingowych, prowadzonych jakby w ukryciu, jakby na pograniczu prawa.

Jak tłumaczyć ową naiwną percepcję lobbingu? Przyczyn jest wiele, ale zdaje się, że ta najistotniejsza to po prostu brak obiektywnej wiedzy w tej materii wśród przedstawicieli opinii publicznej. Przy okazji, należy z całą mocą podkreślić degenerację funkcji informacyjnej współczesnych massmediów, niemalże zupełnie nie zainteresowanych przekazywaniem rzetelnych informacji zamiast szybkiej „trzydziestosekundówki” w duchu bulwarowej prasy.

Choć nie bez znaczenia w tej (deformującej odbiór lobbingu) materii pozostaje także obowiązujący profil stosunków przemysłowych. Przykładowo, polska scena przemysłowa przybiera postać chwiejnego korporatyzmu ${ }^{36}$, oznacza to zatem, że strategie lobbingowe nie są na niej często wykorzystywane. Stąd też płynie wniosek o „obcości” i nieprzyzwyczajeniu opinii publicznej, acz nie tylko, do tego typu przedsięwzięć. Może to także wpływać na sposób (właściwy bądź też nieudolny) prowadzenia działań lobbingowych przez organizacje grup interesu, czy też wciąż niską profesjonalizację działań tego typu.

Tymczasem należy sobie uświadomić, że akcja lobbingowa stanowi dogodne narzędzie działań dla grup interesu, które mogą przy jej zastosowaniu w sposób efektywny realizować swoje interesy. Dziś ten stan rzeczy w ustabilizowanych demokracjach nikogo specjalnie nie dziwi, a bywa nawet uznawany za rzecz dość oczywistą. Reasumując, warto zaznaczyć, że w miarę konsolidacji polskiego systemu demokratycznego uwidoczni się większa relewantność działań lobbingowych, ale także dojdzie do ich znacznej profesjonalizacji. Wszystko to daje nam nadzieję na przyznanie lobbingowi właściwego miejsca w polskich stosunkach przemysłowych.

\section{Summary}

\section{The role of lobbying in industrial relations in Poland}

Lobbying is one of the strategies applied by groups of interest. Like any other strategy it is to help achieve the goals that a particular group identifies and articulates. Paradoxically, the greatest value and the strongest enemy of lobbying is its popularity. On one hand lobbying is a series of activities that group elites willingly (e.g. in the U.S.) employ to achieve their interests. On the other hand, though, referring to the notion of lobbying in various contexts,

z Antykorupcyjną Koalicją Organizacji Pozarządowych (należą do niej m.in. Fundacja im. Stefana Batorego, Helsińska Fundacja Praw Człowieka, Stowarzyszenie 61). Prace nad alternatywnym projektem toczą się również od kilku miesięcy w gronie koalicji rządzącej, w szczególności wśród posłów i specjalistów zgrupowanych wokół Julii Pitery.

36 J. Sroka, Rola publicznych instytucji decyzyjnych w dialogu społecznym, w: Dialog społeczny. Najnowsze dyskusje i koncepcje, red. R. Towalski, Centrum Partnerstwa Społecznego „Dialog”, Instytut Spraw Publicznych, Warszawa 2007 , s. 50. 
whether in PR, marketing or journalism, it raises numerous questions. The latter, i.e. the journalistic context distorts it most severely. It is journalism that applies the name of lobbying to mysterious, to put it mildly, and dubious interactions between the private and the political sectors, thereby implying a rather derogatory 'image' of this instrument in public opinion, which is especially the case in Central and Eastern Europe, including Poland.

However, lobbying is more than a handy tool to achieve particular, strictly business interests, it is also an important route to implement social interests. It can be easily used by large economic groups of interest, trade unions or business organizations, wrestling with the strong third party of industrial relations, the state. By this token lobbying becomes a component of industrial relations, and by no means is it a worse party, one that is less socially-oriented and more like an 'old boys' network', but a party which can efficiently contribute to a specified social interest to be implemented in the labor market. In order to make it possible, though, appropriate regulations, conditions, and factors of a legal, organizational and cultural nature need to be developed. A profound change in this field does not seem feasible in Poland, which becomes clear when reading the long-awaited law on lobbying currently in the legislative process. Maybe we should not be very surprised, given that our industrial arena is highly susceptible to hybrid and ephemeral solutions, and the issue of making appropriate use of lobbying also leaves a margin for uncertainty and deformation.

Despite these concerns and limitations caused by industrial relations it is worth improving and creating the proper environment for lobbying activity in Poland, which the authors of this paper try to demonstrate. 
